\title{
Ruminal fermentation and forestomach digestion of peas by dairy cows
}

\author{
GR Khorasani 1, E Okine 2, R Corbett 2, JJ Kennelly 1 \\ Department of agricultural, food and nutritional science, University of Alberta, Edmonton, \\ AB T6G 2P5 ; ${ }^{2}$ Alberta agriculture, food and rural development, Edmonton, AB T6H 4P2, Canada
}

Protein feeds commonly used in dairy cow rations in Western Canada include soybean meal, canola meal, and distiller dried grains. Peas are locally grown and contain relatively high levels of protein $(24 \%)$ and starch $(48 \%)$, but information on the digestion and utilization of peas by lactating dairy cows are limited. Therefore, the objective of this study was to determine the effects of including peas as a replacement for soybean meat in the diet of dairy cows on ruminal digestion and metabolites and nutrient flow to the intestine. This study was also designed to allow identification of the optimal dietary inclusion level of peas.

Four late-lactation (200 \pm 23 days) Holstein cows fitted with rumen and duodenal cannulae were assigned to four dietary treatments as a $4 \times 4$ Latin square design with a 3 week experimental period. Cows were fed four diets ad libitum with a $50: 50$ forage : concentrate ratio (DM basis). Forage components consisted of $25 \%$ alfalfa silage and $25 \%$ brome-grass silage. A $19 \%$ CP concentrate was prepared based on barley, corn and soybean meal. In the test diets, peas replaced soybean meal at the levels of $0.33 \%, 67 \%$ and $100 \%$. Rumen liquid was sampled for $\mathrm{pH}$ and volatile fatty acid (VFA) determination. Chromium mordanted alfalfa silage was used as a marker to measure duodenal flow of $\mathrm{N}$ and bacterial proteins. Daily duodenal flow of bacterial $\mathrm{N}$ was estimated from the diaminopimelic acid (DAPA) concentration of duodenal DM and the N/DAPA ratio of isolated rumen bacteria. Data were analyzed as a Latin square design. The rumen metabolites and rumen $\mathrm{pH}$ data were analyzed as a repeatedmeasures design.

Dry matter intake $(21.6 \pm 0.4)$ and milk production $(21.5 \pm 0.7)$ were not influenced $(P>0.5)$ by substitution of peas for soybean meal. Average rumen $\mathrm{pH}$ decreased linearly $(\mathrm{P}<0.01)$ with increasing level of peas in the diet. Substitution of peas for soybean meal resulted in a cubic response in the concentration of total VFA, acetate, and total branch-chain fatty acids $(P<0.05)$, but no effect on the concentration of propionate and acetate : propionate ratio were observed. Substitution of peas for soybean meal resulted in a linear increase in the concentration of rumen butyrate, isovalerate, and valerate and a cubic effect on rumen caproate concentration. Rumen DM $(12.2 \pm 0.6 \mathrm{~kg} / \mathrm{day})$ and total ingesta pool size $(82.1 \pm 2.1 \mathrm{~kg} /$ day) were not influenced by treatment $(P>0.05)$. As the proportion of peas in the diet increased, a cubic response on the following parameters were observed : rumen bacterial yield ( $\mathrm{g} \mathrm{N} / \mathrm{kg}$ ADOM) and duodenal flow of total $N$, nonammonia $\mathrm{N}$, bacterial $\mathrm{N}$ and bacterial $\mathrm{N}$ as percent of duodenal non-ammonia $\mathrm{N}$.

On the basis of ruminal fermentation data and nutrient flow to the duodenum, we conclude that peas can replace about $70 \%$ of soybean meal protein in the diet of late-lactation dairy cows. As late- lactation dairy cows require less ruminal escape protein and peas have a lower ruminal escape protein concentration than soybean meal (effective degradability of $\mathrm{CP}$, $12 \%$ vs $28 \%$ respectively), further research is required to investigate the efficacy of peas in the diet of early-lactation dairy cows. 